M. Chernets

Professor

National Aviation University

Department of Engineering, Standardization and Certification

Ukraine

\section{A. Kornienko}

Associate Professor National Aviation University Department of Engineering, Standardization and Certification Ukraine

\section{O. Radko}

Associate Professor National Defence University of Ukraine named after Ivan Cherniakhovskyi Aviation Departmen Ukraine

A. Radionenko
Associate Professor
State Higher Educational Institution
"Priazovsky State Technical University"
Department of Mechanical
Engineering Technologies
Ukraine

Prediction of the Contact Pressures and Resource of Metal-Polymer Linear Cylindrical Plain Bearings

Different types of linear bearings (guides) are widely used in practice in various equipment, as in many other areas of human activity. In particular, this applies to cylindrical guides (linear plain bearings) of reciprocating motion. However, despite their considerable distribution, in fact, there are no reasonable methods for calculating the wear and service life of not only metal but also metal-polymer linear bearings. According to the author's method, the influence of load, base diameter and radial clearance on the maximum initial pressures in this bearing was investigated within the plane contact problem of the theory of elasticity. Further, using the computational method according to the author's tribokinetic model of wear during sliding friction, the effect of the composite bushing wear on the change of the initial contact characteristics (contact pressures and contact angle) was evaluated. The forecast calculation of the service life of the bearing depending on the above factors is also carried out. Quantitative and qualitative regularities of dependence of contact pressures and a resource on the accepted factors are established.

Keywords: metal-polymer linear cylindrical plain bearings, calculation method of contact parameters, resource calculation method, polymer composites

\section{INTRODUCTION}

Linear plain bearings (plain and cylindrical guides), which provide reciprocating motion in mobile connections, are widely used both in mechanical engineering and in many other areas. In particular in forging and pressing equipment, metal - cutting machines, hoisting - transport mechanisms, agricultural machines, packing equipment, equipment of food and processing industry, equipment for wood and plastics processing, aerospace technology, positioning drives, laboratory and medical equipment, measuring devices, etc.

Cylindrical guides are also quite common. They have a base made of steel or cast iron, and a slider bushing made of bronze or anti-friction cast iron. However, a hybrid combination of materials friction pair is increasingly used, when one of its elements may be made of composite polymeric materials. In particular, such technologies are used to restore worn contact surfaces by applying a layer of composite material. In these hybrid friction pairs, the materials will have fundamentally different strength, elastic characteristics and wear resistance.

However, even for the classical type of linear plain bearings made of metallic materials, no appropriate calculation methods have been developed, although this is necessary for the needs of engineering practice. To study the contact strength, wear and resource of this

Received: April 2021, Accepted: June 2021

Correspondence to: Dr A. Kornienko, National Aviation University, Aerospace faculty, 1, Liubomyra Huzara ave., 03058 Kyiv, Ukraine.

E-mail: anatoliykor80@gmail.com

doi:10.5937/fme2103627C

(C) Faculty of Mechanical Engineering, Belgrade. All rights reserved type of linear bearings with metal elements, the known computational methods [1-6] and numerical methods (Ansys) [7-9] were not used. With regard to metalpolymer linear bearings, there are no effective and sound computational methods for their study. Only in [10-12] experimental studies and numerical modeling by FEM of contact pressures and their changes due to wear in polymer composite bearings were performed. As for the methods of calculation (simulation) of the resource of this type of bearings, they are absent. Also by the method of triboelements [13] a certain attempt was made to estimate the wear of a thin elastic layer on the rigid bushing of the sliding bearing during reciprocating motion.

In practice, plain bearings with rotational shaft motion are also widespread, where hydrodynamic lubrication is realized, in particular, the study of this type of bearings is presented in [14-16]. However, due to the occurrence of the oil film bearing layer at a steady rotational motion, there is no mechanical contact between the shaft and the bushing, which is a feature of such bearings. Accordingly, the wear of its contact parts will be absent here, unlike plain bearings of rotary and linear motion operating in conditions of boundary or dry friction. In hydrodynamic friction, it is also customary to determine the pressure in the oil film and the thickness of the oil layer, rather than contact pressures, as a criterion for their bearing capacity. Hydrodynamic friction mode cannot be provided in linear plain bearings.

Instead, according to the developed author's methods for the study of plain bearings with metal elements [1722], in [23-25] the wear kinetics of cylindrical linear plain bearings with metal elements operating in con- 
ditions of boundary friction was studied. Regarding the study of this structures type with reciprocating motion of one of the elements, they are known in the literature regarding pneumatic cylinders [26-29] and hydraulic cylinders [30-33]. This is not about wear, but about determining the friction force in the piston and rod seals, taking into account their geometry, diameter, operating conditions in the cylinders (pressure, speed, type of friction, etc.).

Below are the main principles of the developed computational method for the study of contact pressures and resource of metal-polymer linear cylindrical plain bearings with a bushing of polymer composites Moglice and DK6. The results of evaluation of the contact parameters from the load, the diameter of the base of the linear bearing, the radial clearance in the connection, taking into account the wear and service life of the bearing are also presented.

\section{PROBLEM FORMULATION}

There are different types of linear cylindrical guides with one (Fig. 1a), two (Fig. 1b) and four (Fig. 1c, d) bases.

A linear cylindrical sliding bearing (cylindrical guide) with one base (Fig. 1a) is modeled by an elastic base 2, along which an elastic slider 3 with a nonmetallic bushing 1 performs a rectilinear reciprocating motion at a constant speed $v$ (Fig. 2).

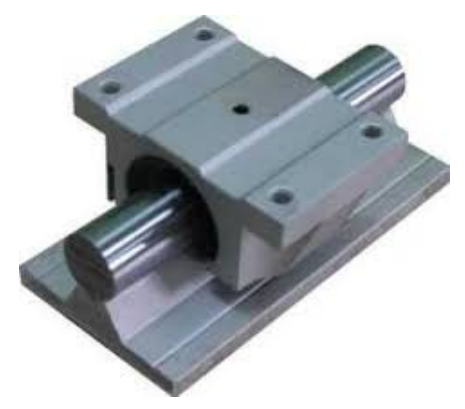

a)

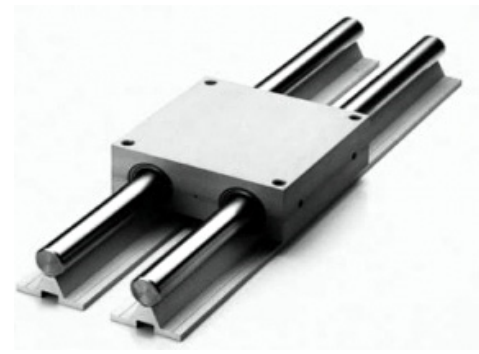

b)

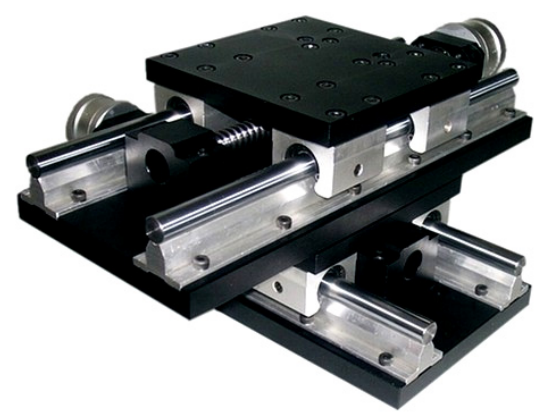

c)

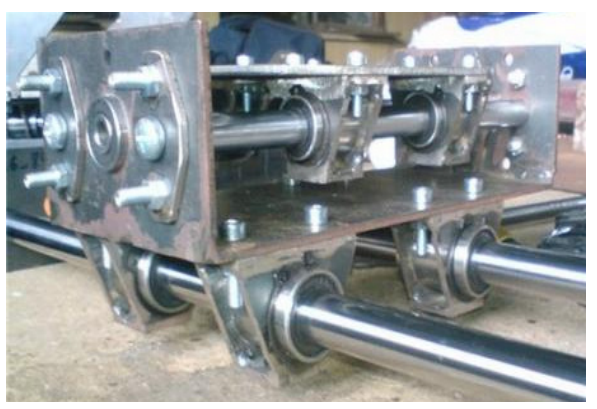

d)

Figure 1. Linear cylindrical plain bearings

In the guide (Fig. 2) between the polymer bushing 1 with an inner radius $R_{1}$ and the steel base of the radius $R_{2}$, there is a radial clearance $\varepsilon=R_{2}-R_{1}$. The polymer bushing of the slider and the steel base of the guide have significantly different elastic characteristics and different wear resistance. A static force $F$ is applied to the slider 3 , under the influence of which contact pressures $p(\alpha)$ arise in the contact area $2 \alpha_{0}$, the magnitude and distribution of which is unknown. Further study of this guide was carried out as a plane contact problem of the theory of elasticity for cylindrical bodies, which are in internal contact under the action of the consolidated radial force $N=F / l_{1}$.

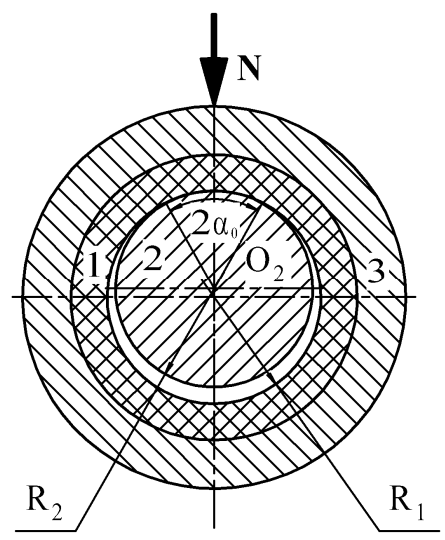

Figure 2. Calculated scheme of linear cylindrical plain bearing

\section{CALCULATION METHOD OF CONTACT PRESSURES AND RESOURCE}

In accordance with $[17,18,25]$ an integro-differential equation of a certain type is used to determine the magnitude and distribution of the initial contact pressures $p(\alpha)$ in the investigated conjugation of cylindrical bodies of close radii. For its approximate solution by the collocation method, the function $p(\alpha)$ is taken in the form

$$
p(\alpha) \approx E_{0} \varepsilon \sqrt{\tan ^{2} \frac{\alpha_{0}}{2}-\tan ^{2} \frac{\alpha}{2}}
$$

where $\alpha= \pm 0.5 \alpha_{0}$ - the collocation points; $E_{0}=$ $\left(e_{4} / R\right) \cos ^{2}\left(\alpha_{0} / 4\right)$ - the collocation coefficient; $Z=\left(1+\kappa_{1}\right)\left(1+\mu_{1}\right) E_{2}+\left(1+\kappa_{2}\right)\left(1+\mu_{2}\right) E_{1}, \quad e_{4}=$ $e_{4}=4 E_{1} E_{2} / Z ; E$ - Young's modulus; $\kappa=3-4 \mu$ - the 
plane strain state; $\mu$ - Poisson's ratio.

The contact zone $2 R_{2} \alpha_{0}$ of the guide elements is set if you know the contact semiangle $\alpha_{0}$, which is found at a given value of the load $N$ according to the following equation of equilibrium of forces applied to the base 2 :

$$
\begin{aligned}
& N=R_{2} \int_{-\alpha_{0}}^{\alpha_{0}} p(\alpha) \cos \alpha d \alpha=4 \pi R_{2} E_{0} \varepsilon \sin ^{2}\left(\alpha_{0} / 4\right), \\
& 0<\alpha_{0}<90^{\circ}
\end{aligned}
$$

When $\alpha=0$, there is a maximum initial contact pressure $p(0)$, which characterizes the load carrying capacity of the guide

$$
p(0)=E_{0} \varepsilon \tan \left(\alpha_{0} / 2\right) .
$$

When the polymer bushing wears out, the contact angle $2 \alpha_{0}$ will increase and the initial contact pressures $p(0)$ will decrease. Maximum contact pressure $p(0, t, h)$ in the guide during wear

$$
p(0, t, h)=p(0)-p(0, h) .
$$

The change $p(0, h)$ of the maximum initial contact pressure due to wear of the polymer bushing is calculated by the formula $[18,20,22,25]$

$$
p(0, h)=E_{0} C_{h} \varepsilon_{h} \tan \left(\frac{\alpha_{0 h}}{2}\right) .
$$

where $\varepsilon_{h}=h_{1 *}\left(K_{1}+h_{1}^{\prime}\right) ; C_{h}-$ the wear rate indicator; $h_{1}^{\prime}=\frac{h_{2}}{h_{1}}=\frac{B_{1} \tau_{01}^{m_{1}}\left(\tau-\tau_{02}\right)^{m_{2}}}{B_{2} \tau_{02}^{m_{2}}\left(\tau-\tau_{01}\right)^{m_{1}}} K_{2} \quad[20], \quad \tau=f p(0)$ maximum Coulomb specific friction force; $h_{1 *}$ allowable wear of the bushing;

$B, m, \tau_{0}$ - characteristics of wear resistance of materials in a tribopair, determined by the least squares method based on the results of experimental studies of wear at different levels of specific friction forces $\tau$ [20, 22, 25]; $K_{1}=1, K_{2}\langle 1$ - coefficients of mutual overlap of the guide elements during moving contact.

An equation of the following type is used to establish the contact semiangle $\alpha_{0 h}$ at wear

$$
N=4 \pi R_{2} E_{0}\left(\varepsilon+C_{h} \varepsilon_{h}\right) \sin ^{2} \frac{\alpha_{0 h}}{4},
$$

The resource of the cylindrical sliding guide is defined in the form of the limiting path of sliding friction $L_{1}$ of the composite bushing

$$
\begin{aligned}
& L_{1 *}=\frac{-B_{1} \tau_{01}^{m_{1}}}{C_{h} \tau_{0 h}\left(1+h_{1}^{\prime}\right)\left(1-m_{1}\right) K_{1}} * \\
& *\left\{\left(\tau-\tau_{01}\right)^{1-m_{1}}-\left[\left(\tau-\tau_{01}\right)-h_{1 *}\left(1+h_{1}^{\prime}\right) C_{h} \tau_{0 h}\right]^{1-m_{1}}\right\} .
\end{aligned}
$$

where $L_{1 *}=v t_{*}, t_{*}$ - service life of the guide in hours; $\tau_{0 h}=f p(0, h)$.

\section{NUMERICAL SOLUTION, RESULTS AND DISCUSSION}

Data for calculation: $F=500,750,1000,2000 \mathrm{~N} ; N=$ $F / l_{1}=5,7.5,10,20 \mathrm{~N} / \mathrm{mm} ; \varepsilon=0.05,0.075,0.1 \mathrm{~mm}$ (clearance fit H9/d9); $D_{2}=40,50 \mathrm{~mm} ; l_{1}=100 \mathrm{~mm}$ bushing length, $l_{2}=500 \mathrm{~mm}$ - base length; $K_{2}=0.2$, $K_{1}=1 ; f=0.09-$ boundary friction; $h_{1 *}=0.5 \mathrm{~mm}$. Materials of elements of a cylindrical guide:

slider bushing: polymer composites Moglice and DK6,2)Moglice $-E_{M}=11200 \mathrm{MPa}, \mu_{M}=0.4, \sigma_{c}=$ $120 \mathrm{MPa}, \mathrm{DK} 6-E_{D K}=6500 \mathrm{MPa}, \mu_{D K}=0.4, \sigma_{c}=$ $140 \mathrm{MPa} ; B_{1}=1.2 \cdot 10^{11}, \quad m_{1}=1.9, \tau_{01}=0.05 \mathrm{MPa}-$ their wear resistance characteristics;

base: carbon steel S45 $-E_{2}=210000 \mathrm{MPa}, \mu_{2}=0.3$; $B_{2}=2.2 \cdot 10^{12}, m_{2}=2.1, \tau_{02}=0.1 \mathrm{MPa}$.

Moglice is the anti-friction polymer epoxy-based material of German company «Diamant», which is used for sliding surfaces renovation. Material DK6 is created on the basis of an epoxy matrix with various fillers and contains fillers, in particular molybdenum disulfide, graphite.

According to the above computational methods, the calculation of the maximum contact pressures $p(0)$ and their transformation $p(0, t, h)$ due to wear was performed; angles $\alpha_{0}$ of the initial contact and their magnitude $\alpha_{0 h}$ during wear of the slider, and service life of the guide $L_{1}$. Their results are given in Fig. $3-7$. Figures (a) correspond to Moglace composite, and figures (b) - DK6 composite.

Fig. 3 shows the quantitative and qualitative dependencies of $p(0)$ on radial clearance $\varepsilon$ and at different loads $N$ on the guide. With a smaller diameter of the bushing with radial clearance increasing, the pressures $p(0)$ increase almost linearly, and with a larger diameter, this dependence becomes close to linear. Quantitative analysis of the obtained results of the calculation shows that: increasing the radial clearance $\varepsilon$ twice leads to an increase in $\sqrt{2}$ times the pressures $p(0)$ regardless of the change in the load $N$ and the base diameter $D_{2}$; a 4-fold increase in the load leads to an increase in 2 times the maximum contact pressures $p(0)$ regardless of changes in the values of the radial clearance, the base diameter $D_{2}$ and the type of composite material. In the guide with the Moglice bushing, the Young's modulus which is 1.3 bigger than DK6, there are pressures more than $\approx \sqrt{E_{M} / E_{D K}}$ times.

Fig. 4 represents the change in the maximum contact pressure $p(0)$ when the bushing wears. The nature of its change will be nonlinear with increasing radial clearance.

The qualitative decrease of $p(0)$ will be $3.43 \ldots 3.49$ times depending on the load, radial clearance and diameter. With increasing load $N 4$ times $p(0, t, h)$ will also double, as will the pressures $p(0)$ (Fig. 3).

Fig. 5 shows the qualitative and quantitative dependences of angle $\alpha_{0}$ on the radial clearance and the load. 


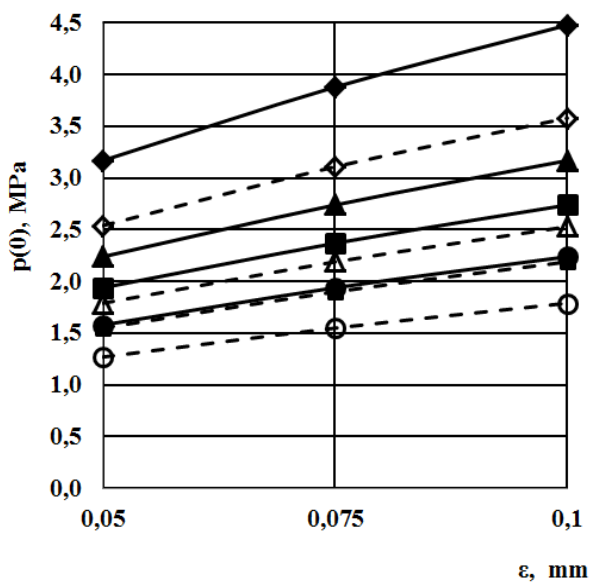

a)

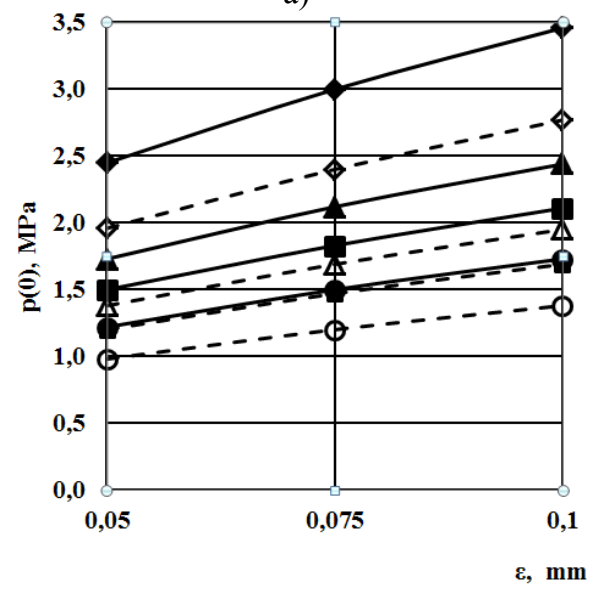

b)

Figure 3. Influence of the radial clearance and load on the maximum contact pressures: $D_{2}=\mathbf{4 0} \mathrm{mm}$ - solid lines, $D_{2}=$ $50 \mathrm{~mm}$ - dashed lines

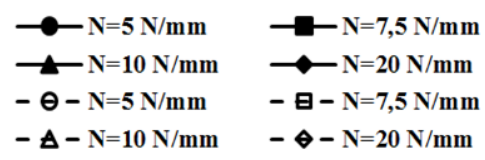

It is established that $\alpha_{0}$ will decrease nonlinearly with clearance and load increasing. Increasing the radial clearance twice helps to reduce the angle $\alpha_{0}$ by $\sqrt{2}$ times at all load values. Accordingly, increasing the load four times gives an increase in angles $\alpha_{0}$ twice.

In fig. 6 is shown the nature of the influence of the bushing wear on the angle of the tribocontact.

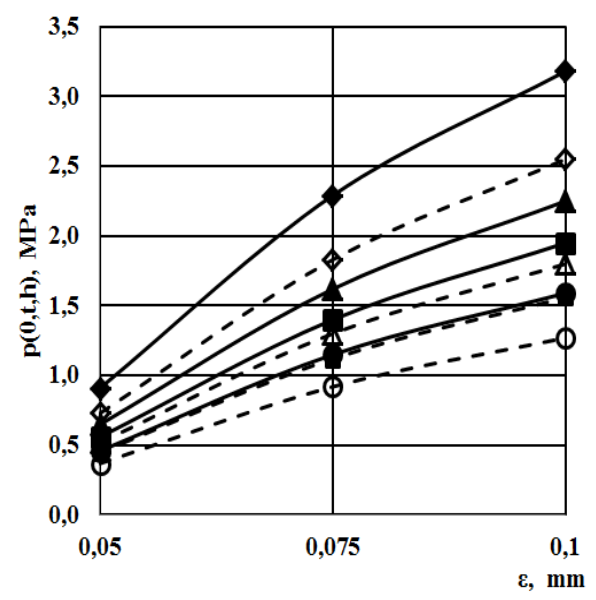

a)

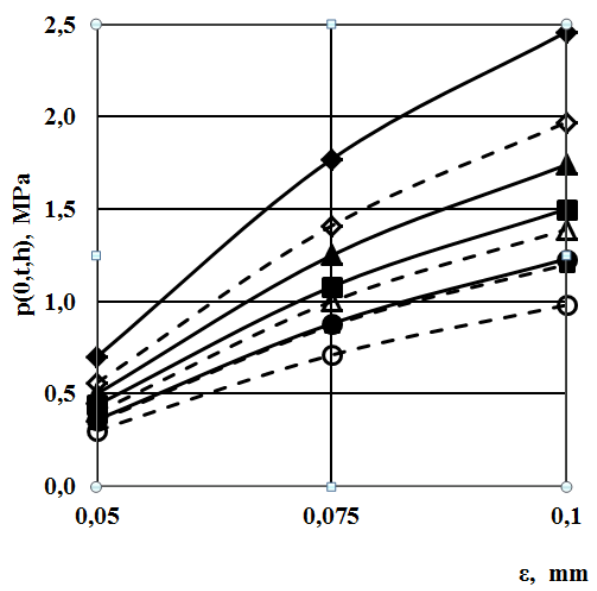

b)

Figure 4. Influence of the wear on the maximum contact pressures
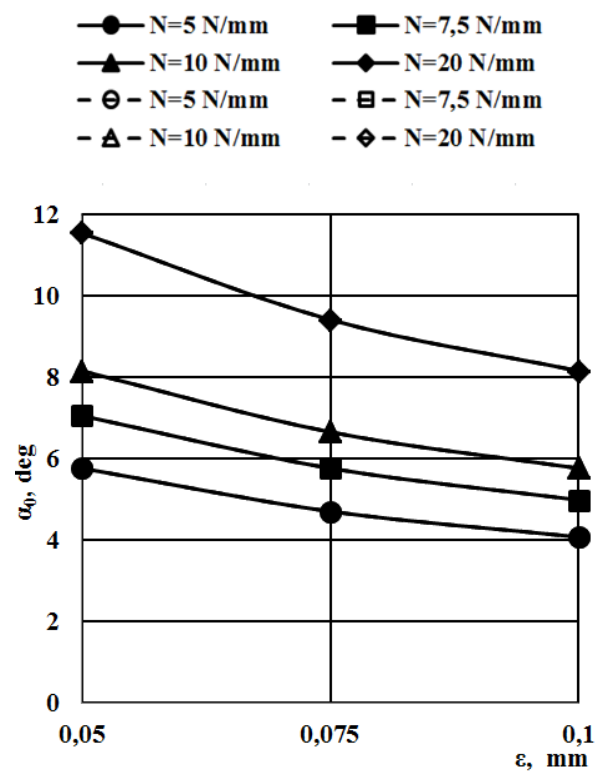

a)

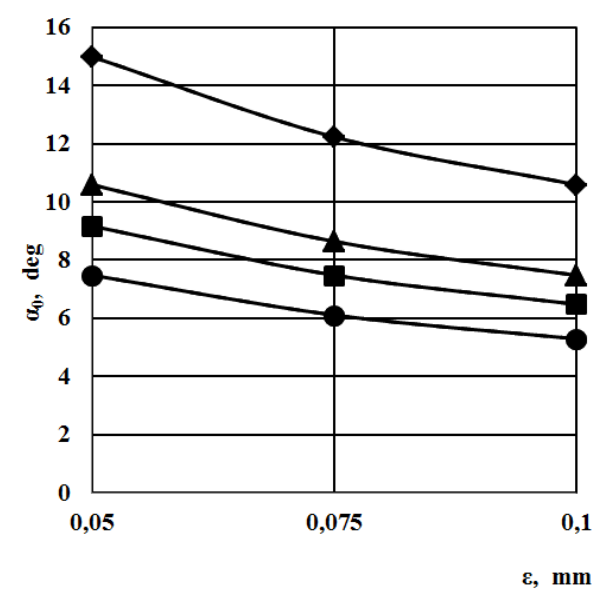

b)

Figure 5. Influence of the radial clearance and the load on the contact angles

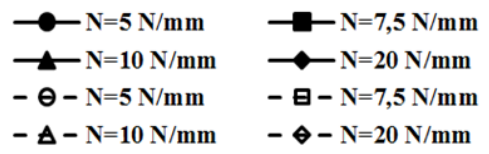




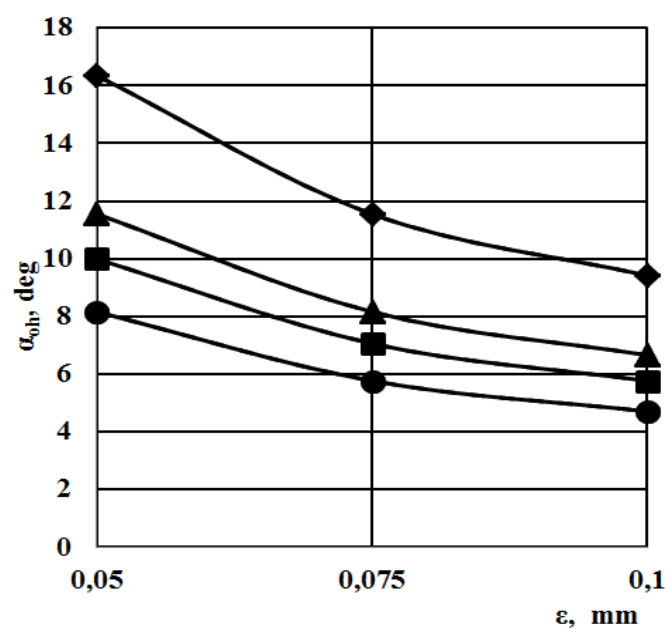

a)

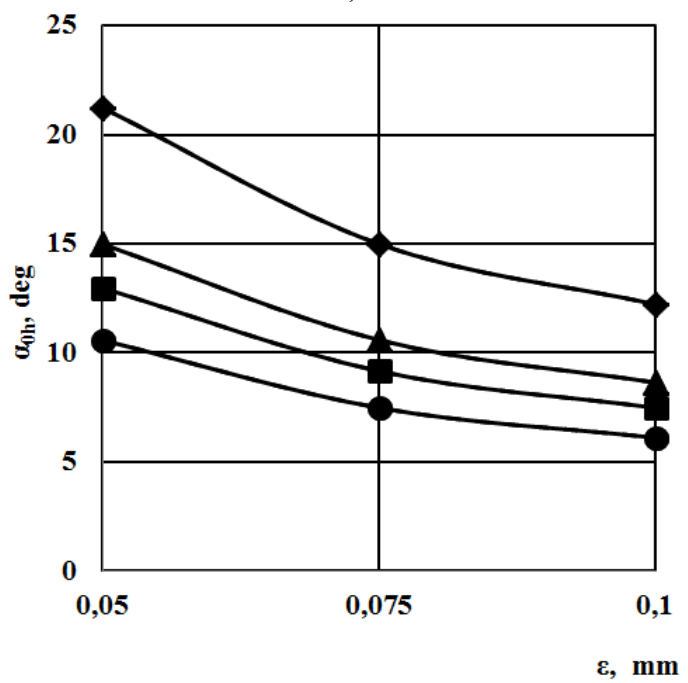

b)

Figure 6. Influence of wear on the angles of the tribocontact
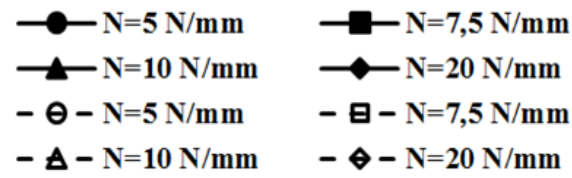

It is also observed a nonlinear nature of this dependence, the largest at the maximum accepted load. Increasing the clearance twice leads to a decrease in the angle $\alpha_{0 h}$ by 1.73 times, which is approximately equal to $E_{M} / E_{D K}$. Instead, when the load is quadrupled, the angle $\alpha_{0 h}$ will be twice as large.

Fig. 7 shows the qualitative and quantitative impact of the radial clearance and the load on the resource of the guide $L_{1}$ until the bushing 1 reaches the allowable wear $h_{1 *}=0,5 \mathrm{~mm}$.

The increase in the radial clearance causes a significant decrease in the resource of the guide due to the increase in maximum contact pressures. As the load increases, this reduction in resource will be more significant. Reducing the diameter also significantly reduces the durability (Fig. 7).

Doubling the radial clearance causes the sliding distance to decrease by $2.19 \ldots 2.91$ times (Moglice) and $2.40 \ldots 3.40$ times (DK6) depending on the load and the base diameter (Table 1; 2).

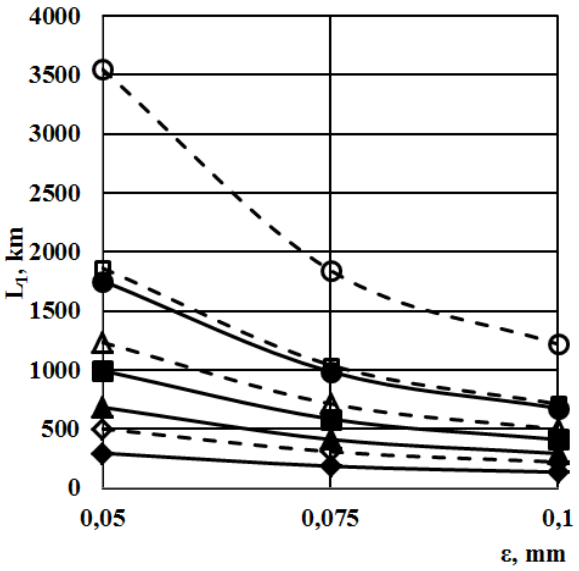

a)

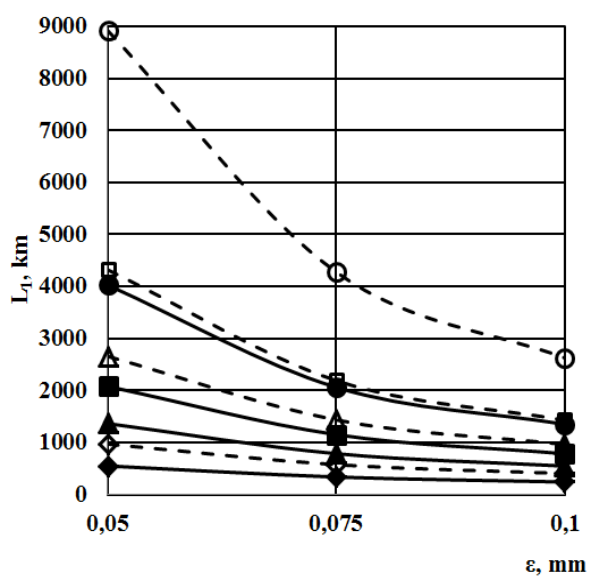

b)

Figure 7. Dependence of the guide service life on the radial clearance

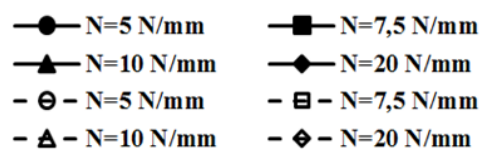

Table 1. Guide resource $L_{1(\mathrm{M})}$ for a bushing made of Moglice

\begin{tabular}{|c|c|c|c|c|c|c|c|c|}
\hline$\varepsilon, \mathrm{mm}$ & \multicolumn{8}{|c|}{ Sliding distance $L_{1}, \mathrm{~km}$} \\
\hline 0,05 & 1756 & 996 & 685 & 296 & 3548 & 1863 & 1234 & 502 \\
\hline 0,075 & 987 & 586 & 413 & 186 & 1845 & 1042 & 715 & 308 \\
\hline \multirow{2}{*}{$\frac{0,1}{N, \mathrm{~N} / \mathrm{mm}}$} & 677 & 412 & 294 & 135 & 1219 & 713 & 498 & 221 \\
\hline & 5 & 7,5 & 10 & 20 & 5 & 7,5 & 10 & 20 \\
\hline \multirow{2}{*}{$\begin{array}{r}\text { Increase } \\
\varepsilon, \text { times }\end{array}$} & \multicolumn{4}{|c|}{$D_{2}=40 \mathrm{~mm}$} & \multicolumn{4}{|c|}{$D_{2}=50 \mathrm{~mm}$} \\
\hline & \multicolumn{8}{|c|}{ Decrease $L_{1}$, times } \\
\hline 2 & 2,59 & 2,42 & 2,33 & 2,19 & 2,91 & 2,61 & 2,47 & 2,27 \\
\hline
\end{tabular}

Table 2. Guide resource $L_{1(\mathrm{DK})}$ for a bushing made of DK6

\begin{tabular}{|c|c|c|c|c|c|c|c|c|}
\hline$\varepsilon, \mathrm{mm}$ & \multicolumn{8}{|c|}{ Sliding distance $L_{1}, \mathrm{~km}$} \\
\hline 0,05 & 4026 & 2078 & 1364 & 548 & 8918 & 4320 & 2655 & 968 \\
\hline 0,075 & 2060 & 1150 & 785 & 335 & 4274 & 2190 & 1432 & 573 \\
\hline 0,1 & 1350 & 783 & 545 & 240 & 2624 & 1429 & 963 & 403 \\
\hline$N, \mathrm{~N} / \mathrm{mm}$ & 5 & 7,5 & 10 & 20 & 5 & 7,5 & 10 & 20 \\
\hline \multirow{2}{*}{$\begin{array}{r}\text { Increase } \\
\varepsilon, \text { times } \\
\end{array}$} & \multicolumn{4}{|c|}{$D_{2}=40 \mathrm{~mm}$} & \multicolumn{4}{|c|}{$D_{2}=50 \mathrm{~mm}$} \\
\hline & \multicolumn{8}{|c|}{ Decrease $L_{1}$, times } \\
\hline 2 & 2,59 & 2,42 & 2,33 & 2,19 & 2,91 & 2,61 & 2,47 & 2,27 \\
\hline
\end{tabular}


Table 3. The impact of the radial clearance on the relative reduction of $L_{1(\mathrm{DK})} / L_{1(\mathrm{M})}$

\begin{tabular}{|c|c|c|c|c|c|c|c|c|c|}
\hline \multirow{2}{*}{\begin{tabular}{|c|} 
Composite \\
DK6
\end{tabular}} & \multirow{2}{*}{$\frac{\varepsilon, \mathrm{mm}}{0,05}$} & \multicolumn{8}{|c|}{ Sliding distance $L_{1}, \mathrm{~km}$} \\
\hline & & 4026 & 2078 & 1364 & 548 & 8918 & 4320 & 2655 & 968 \\
\hline Moglice & 0,05 & 1756 & 996 & 685 & 296 & 3548 & 1863 & 1234 & 502 \\
\hline \multicolumn{2}{|c|}{$L_{1(\mathrm{DK})} / L_{1(\mathrm{M})}$, times } & 2,29 & 2,09 & 1,99 & 1,85 & 2,51 & 2,32 & 2,15 & 1,93 \\
\hline DK6 & 0,075 & 2060 & 1150 & 785 & 335 & 4274 & 2190 & 1432 & 573 \\
\hline Moglice & 0,075 & 987 & 586 & 413 & 186 & 1845 & 1042 & 715 & 308 \\
\hline \multicolumn{2}{|c|}{$L_{1(\mathrm{DK})} / L_{1(\mathrm{M})}$, times } & 2,09 & 1,96 & 1,90 & 1,80 & 2,32 & 2,10 & 2,00 & 1,86 \\
\hline DK6 & 0,1 & 1350 & 783 & 545 & 240 & 2624 & 1429 & 963 & 403 \\
\hline Moglice & 0,1 & 677 & 412 & 294 & 135 & 1219 & 713 & 498 & 221 \\
\hline \multicolumn{2}{|c|}{$L_{1(\mathrm{DK})} / L_{1(\mathrm{M})}$, times } & 1,99 & 1,90 & 1,85 & 1,78 & 2,15 & 2,00 & 1,93 & 1,82 \\
\hline \multicolumn{2}{|c|}{$\operatorname{Load} N, \mathrm{~N} / \mathrm{mm}$} & 5 & 7,5 & 10 & 20 & 5 & 7,5 & 10 & 20 \\
\hline \multicolumn{2}{|c|}{ Diameter $D_{2}, \mathrm{~mm}$} & \multicolumn{4}{|c|}{40} & \multicolumn{4}{|c|}{50} \\
\hline
\end{tabular}

The resource of the guide bushing made of DK6 will be $1,77 \ldots 2,51$ times greater than the resource of the guide bushing made of Moglice (Table 3) depending on the radial clearance in the joint and the base diameter.

\section{CONCLUSION}

The use of hybrid pairs of materials with significantly different strength, elastic characteristics, deformability and wear resistance in linear plain bearings requires the creation of appropriate calculation methods by which at the design stage it would be possible to assess contact pressures, wear and service life. Due to their absence, the authors conducted research aimed at developing an appropriate method for solving the contact problem of the theory of elasticity with wear of a hybrid tribosystem according to the author's tribokinetic model of material wear kinetics.

Using polymer composites Moglice and DK6, the influence of the load, the bushing diameter and the radial clearance on the quantitative and qualitative patterns of change of contact parameters (initial and while the bushing wears) and the resource of this type of linear bearings from the specified factors was investigated. The above calculation results indicate the effectiveness of the presented method for estimating the contact parameters in engineering practice in the design of metal-polymer cylindrical linear bearings.

\section{REFERENCES}

[1] Goryacheva, I.G. and Dobychin, N.M.: Contact problems in tribology. Mashinostroenie, Mosvow, 1988.

[2] Teplyi, M.I.: Determination of contact parameters and wear in cylindrical sliding bearings, Journal Friction and Wear, Vol. 6, pp. 895-902, 1987.

[3] Kuzmenko A.G.: Development of methods of contact tribomechanics. KhNU, Khmelnytsky, 2010.

[4] Dykha, A., Sorokatyi, R., Makovkin, O. and Babak, O.: Calculation-experimental modeling of wear of cylindrical sliding bearings, Eastern-European
Journal of Enterprise Technologies, Vol. 89, No. 1, pp. 51-59, 2017. doi:10.15587/1729-4061.2017. 109638

[5] Dykha, A., Marchenko, D.: Prediction the wear of sliding bearings, International Journal of Engineering \& Technology, Vol. 7, No. 2.23, pp. 48, 2018. doi: 10.14419/ijet.v7i2.23.11872

[6] Kindrachuk, V., Fedelich, B., Rehmer B. and Peter, F.: Computational Methods for Lifetime Prediction of Metallic Components under HighTemperature Fatigue, Metals, Vol. 9, Iss. 4, Article Number 390, 2019. doi: 10.3390/met9040390

[7] Sorokatyi, R.V.: Modeling the behavior of tribosystems using the method of triboelements, Journal of Friction and Wear, Vol. 23, pp. 12-18, 2002.

[8] Sorokatyi, R.V., Pisarenko, V.G. and Dykha M.A.: Analysis of Wear Surface Geometry Formation in Plain Bearings with Misaligned Shaft and Bush Axes, Journal of Friction and Wear, Vol.34, No.4, pp.274-280,2013. doi:10.3103/S10683666130401 19

[9] Sorokatyi, R., Chernets, M., Dykha, A. and Mikosyanchyk, O.: Phenomenological model of accumulation of fatigue tribological damage in the surface lauer of materials, Mechanisms and Machine Science, Vol. 73, 2019, pp. 3761-3769. doi:10.1007/978-3-030-20131-9_371

[10] Rezaei, A., Ost, W., Van Paepegem, W., De Baets and P., Degrieck, J.: Experimental study and numerical simulation of the large-scale testing of polymeric composite journal bearings, Threedimensional and dynamic modeling,Wear,Vol. 270, pp.431-438,2011, doi:10.1016/j.wear.2010.11.005

[11] Rezaei, A., Ost, W., Van Paepegem, W., De Baets, P. and Degrieck, J.: A study on the effect of the clearance on the contact stresses and kinematics of polymeric composite journal bearings under reciprocating sliding conditions, Tribology International, Vol. 48, pp. 8-14, 2012. doi: 10.1016/ j.triboint.2011.06.031

[12] Rezaei, A., Van Paepegem, W., De Baets, P., Ost, W. and Degrieck, J.: Adaptive finite element simulation of wear evolution in radial sliding bearing, Wear, Vol. 296, No. 1-2, pp. 660-671, 2012. doi: 10.1016/j.wear.2012.08.013

[13] Sorokatyi, R.V. Evaluation of the efficiency of sliding bearings during reciprocation, Journal of Friction and Wear, Vol. 24, pp. 15-21, 2003.

[14] Ramaganesh, R., Baskar, S., Arumugam, S. and Ramachandran M.: Finite element analysis of a journal bearing lubricated with nano lubricants, FME Transactions, Vol. 48, No. 2, pp. 476-481, 2020. doi: $10.5937 /$ fme2002476R

[15] Nikolić, N., Torović, T.M., Antonić, Ž.M. and Jovan Dorić, J.: An Algorithm for Obtaining Conditional Wear Diagram of IC Engine Crankshaft Main Journals, FME Transactions, Vol. 39, No.4, pp. 157-164, 2011. 
[16] Marinković, A.: Structural Optimization of Journal Porous Metal Bearing, FME Transactions, (2005) Vol. 33, No. 1, pp. 25-39, 2005.

[17]Chernets, M., Kindrachuk, M. and Kornienko, A. Methodology of calculation of metal-polymer sliding bearings for contact strength, durability and wear, Tribology in Industry, Vol. 42, No. 4, pp. 572-581, 2020. doi: 10.24874/ti.900.06.20.10

[18]Chernets, M.V., Andreikiv, O.E., Liebiedieva, N.M. and Zhydyk, V.B.: A model for evaluation of wear and durability of plain bearing with small small out-of-roundness, Materials Science, Vol. 2, pp. 279-290, 2009. doi:10.1007/s11003-009-9176-5

[19] Chernets, M.V.: A Contact problem for a cylindrical joint with technological faceting of the contours of its parts, Materials Science, Vol. 6, pp. 859-868, 2009. doi:10.1007/s11003-010-9252-X

[20] Chernets, M. and Chernets, Ju.: Generalized method for calculating the durability of sliding bearings with technological out-of-roundness of details, Proc. IMechE. Part J, Journal of Engineering Tribology, Vol. 229, No. 2, pp. 216226, 2015. doi: 10.1177/1350650114554242

[21] Chernets, M.V., Zhydyk, V.B. and Chernets, Yu.M.: Accuracy of evaluation of the service life of a plain bearing according to the generalized cumulative model of wear, Materials Science, Vol. 50, No.1, pp.39-45, 2014. doi:10.1007/s11003-0149689-4

[22] Chernets, M.V.: Prediction of the life of a sliding bearing based on a cumulative wear model taking into account the loading of shaft contour, Journal of Friction and Wear, Vol. 36, No. 2, pp. 163 - 169, 2015. doi: 10.14419/ijet.v7i2.23.11872

[23] Chernets, M., Pashechko, M., Kornienko, A., Chernets, J. and Fedorchuk, S. On the question of methodology of hybrid sliding bearings estimated load capacity and durability evaluation, Adv. Sci. Technol. Res. J., Vol. 14, Iss. 4, pp. 177-184, 2020. doi: 10.12913/22998624/127169

[24] Chernets, M.V. and Lebedeva, N.M.: Investigation of the influence of small non-roundness on the resource of a cylindrical guide, Problems of Tribology, Vol. 4, pp. 52-55, 2006.

[25] Chernets, M.V.: Tribocontact problems for cylindrical joints with technological roundness. Ed. Lublin Polytechnic, Lublin, 2013.

[26] Belforte, G., Conte, M., Manuello, A. and Mazza, L.: Performance and behavior of seals for pneumatic spool valves, Tribology Transactions, Vol. 54, No. 2, pp. 237-246, 2011. doi: 10.1080/ 10402004.2010.538488

[27] Belforte, G., Manuello, A. and Mazza, L.: Test rig for friction force measuremets in pneumatic components and seals, Proc. IMechE. Part J, Journal of Engineering Tribology, Vol. 227, No. 1, pp. 43-59, 2013. doi: 10.1177/1350650112453522

[28] Ho Chang, Chou-Wei Lan, Chih-Hao Chen, TsingTshih Tsung, and Jia-Bin Guo: Measurement of frictional force characteristics of pneumatic cylinders under dry and lubricated conditions, Electrical Review, Vol. 88, No. 7b, pp. 261-264, 2012.

[29] Verheyde, B., Vanhulsel, A., Rombousts, M., Meneve, J., Havermans, D. and Wangenheim, M.: Influence of surface treatment of elastomers on their frictional behavior in sliding contact. Wear, Vol. 226, No. 3-4, pp. 468-475, 2008. doi: 10.1016/ j.wear.2008.04.040

[30] Azzi, A., Maoui, A., Fatu, A., Fily, S. and Souchet, D.: Experimental study of friction in pneumatic seals, Tribology International, Vol. 135, pp. 432438, 2019. doi: 10.1016/j.triboint.2019.03.018

[31] Cristescu, C., Dumitrescu, C., Radoi, R. and Dumitrescu, L.: Experimental Research for Measuring Friction Forces from Piston Sealing at the Hydraulic Cylinders, Tribology in Industry, Vol. 36, No. 4, pp. 465-474, 2014.

[32] Lorinc, M., Szabolcs, F. and Nariman, S.: A practical method for friction identification in hydraulic actuators, Mechatronics, Vol. 21, pp. 350-356, 2011. doi:10.1016/j.mechatronics.2010. 08.010

[33] Tran, X.B., Hafizah, N.N. and Yanada, Y.H.: Modeling of dynamic friction behaviors of hydraulic cylinders, Mechatronics, Vol. 22, No. 1, pp. 65-75,2012. doi:10.1016/j.mechatronics.2011. 11.009

\section{ПРЕДВИЪАЊЕ КОНТАКТНОГ ПРИТИСКА И РЕСУРСА МЕТАЛНО-ПОЛИМЕРНИХ ЛИНЕАРНИХ ЦИЛИНДРИЧНИХ КЛИЗНИХ ЛЕЖАЈЕВА}

\section{М.Чернетс, А.Корниенко, О.Радко, А.Радионенко}

Различити типови линеарних лежајева (вођица) имају широку примену код опреме као и у многим другим областима људске активности. Ово се посебно односи на цилиндричне вођице (линеарне клизне лежајеве) са наизменичним кретањем. И поред широке примене не постоје адекватне методе за прорачун хабања и дужину радног века не само метала, већ и метално-полимерних линеарних лежајева. Према ауторовом методу извршено је истраживање утицаја оптерећења, основног дијаметра и радијалног зазора на максимални почетни притисак код овог типа лежаја у оквиру проблема површинског контакта у теорији еластицитета. Применом методе прорачуна, према ауторовом трибокинетичком моделу хабања у току трења, измерен је утицај хабања композитиних чаура на промену почетних карактеристика контакта (контактни притисак и контактни угао). Такође је прорачуном, на основу наведених фактора, предвиђена дужина трајања радног века лежаја. Утврђене су квантитативне и квалитативне правилности код зависности контактног притиска и ресурса од прихваћених фактора. 